\title{
ASUHAN KEPERAWATAN PADA PASIEN PRE OPERASI PROSTATEKTOMI DENGAN MASALAH KEPERAWATAN ANSIETAS MENGGUNAKAN TEKNIK RELAKSASI NAFAS DALAM DAN DISTRAKSI LIMA JARI
}

\author{
Berticarahmi, Pujiarto \\ Akademi Keperawatan Panca Bhakti Bandar Lampung \\ E-mail : pujiart_77@yahoo.com
}

\begin{abstract}
ABSTRAK
Penderita pre operasi khususnya pre operasi prostatektomi biasanya timbul rasa cemas atau ansietas seperti sulit tidur, aritmia, muncul perasaan tidak nyaman, rasa khawatir yang berlebihan dan bisa sampai menyebabkan panik. Ansietas perlu mendapat perhatian dan intervensi keperawatan karena keadaan emosional pasien yang akan berpengaruh kepada fungsi tubuh pasien menjelang operasi. Ansietas yang tinggi dapat memberikan efek dalam mempengaruhi fungsi fisiologis tubuh. Relaksasi nafas dalam dan distraksi lima jari adalah dua terapi yang dapat dikombinasikan guna mengatasi masalah ansietas pada pasien pre operasi. Tujuan dari penelitian ini adalah untuk mengetahui dampak pemberian terapi nafas dalam dan distraksi lima jari pada pasien pre operasi prostatektomi dengan masalah gangguan kecemasan atau ansietas. Jenis penelitian ini adalah deskriptif dengan menggunakan metode pendekatan studi kasus. Penelitian ini dilakukan dengan dua responden pre operasi prostatektomi dengan masalah ansietas. Berdasarkan hasil penelitian didapati bahwa terapi relaksasi nafas dalam dan distraksi lima jari dapat menurunkan ansietas pada pasien pre operasi prostatektomi. Diharapkan penelitian relaksasi nafas dalam dan distraksi lima jari pada pasien pre operasi dengan masalah kecemasan ini dapat membantu berbagai pihak dalam menyelesaikan masalah ansietas pada pasien pre operasi prostatektomi.
\end{abstract}

Kata Kunci : Ansietas, Distraksi lima jari, Pre operasi Prostatektomi, Relaksasi nafas dalam

\begin{abstract}
In patients with pre-surgery, especially pre-prostatectomy, anxiety or anxiety usually arises such as difficulty sleeping, arrhythmia, discomfort, excessive worry and panic. Anxiety needs attention and nursing intervention because of the emotional state of the patient which will affect the patient's body function before the surgery. High anxiety can have an effect on affecting the physiological functions of the body. Deep breath relaxation and five-finger distraction are two therapies that can be combined to overcome anxiety problems in preoperative patients. The purpose of this study was to determine the effect of giving deep breath therapy and five finger distraction in patients pre prostatectomy with anxiety or anxiety problems. This type of research is descriptive using the case study approach method. This study was conducted with two respondents pre prostatectomy with anxiety problems. Based on the results of the study it was found that deep breath relaxation therapy and five-finger distraction can reduce anxiety in patients pre prostatectomy surgery. It is expected that deep breath relaxation and five-finger distraction studies in preoperative patients with anxiety problems can help various parties in resolving anxiety problems in patients pre prostatectomy surgery.
\end{abstract}

Keywords: Anxiety, Five finger distraction, Pre prostatectomy surgery, Deep breath relaxation 


\section{PENDAHULUAN}

Penderita pre operasi khususnya pre operasi prostatektomi biasanya timbul rasa cemas atau ansietas seperti sulit tidur, aritmia, muncul perasaan tidak nyaman, rasa khawatir yang berlebihan dan bisa sampai menyebabkan panik. Ansietas adalah perasaan yang menetap berupa kekuatan atau kecemasan (was-was, khawatir dan cemas) yang merupakan respon terhadap ancaman yang akan datang. Namun, ansietas merupakan reaksi emosional terhadap penilaian individu yang subyektif, yang dipengaruhi oleh alam bawah sadar dan tidak diketahui secara khusus penyebabnya (Aprianto et al., 2013)

Pada penelitian Rokawie (2017), mengatakan bahwa ansietas dapat dicegah dengan terapi, yaitu terdapat terapi relaksasi nafas dalam, distraksi lima jari atau hipnosis lima jari, terapi genggam jari, terapi dengan aromaterapi, relaksasi imajinasi terbimbing dan masih banyak lagi.

Teknik relaksasi nafas dalam merupakan suatu bentuk asuhan keperawatan, yang dalam hal ini perawat mengajarkan kepada klien bagaimana caranya melakukan nafas dalam, nafas lambat (menahan inspirasi secara maksimal) dan bagaimana menghembuskan nafas secara perlahan. Selain dapat menurunkan intensitas nyeri, teknik relaksasi nafas dalam juga dapat meningkatkan ventilasi paru dan meningkatkan oksigenasi darah (Sari, 2015). Pada penelitan di RSUD RA Kartini Jepara, pemberian terapi relaksasi nafas dalam sangat berdampak pada penurunan tingkat ansietas pada pasien pre operasi. Pada penelitian tersebut menyebutkan bahwa pemberian terapi nafas dalam pada pasien pre operasi yang mengalami cemas memiliki dampak yang baik. Dampak tersebut nampak dalam 15 menit setelah diberikan terapi nafas dalam, pasien dengan ansietas berat tidak lagi mengalami ansietas setelah diberikan terapi relaksasi nafas dalam. Hal ini dapat diartikan bahwa relaksasi nafas dalam efektif untuk menurunkan kecemasan pre operasi (Aprianto et al,. 2013).

Distraksi lima jari atau hipnotis lima jari merupakan salah satu bentuk self hipnosis yang dapat menimbulkan efek relaksasi yang tinggi, sehingga akan mengurangi ketegangan dan stress dari pikiran seseorang (Hastuti dan Arumsari, 2015).

Tujuan penelitian adalah untuk mengidentifikasi persepsi perawat terhadap pengkajian resiko luka tekan Metode Waterlow, Mengidentifikasi persepsi perawat terhadap deskripsi kategori pengkajian resiko luka tekan Metode Waterlow, Mengidentifikasi persepsi perawat terhadap penetapan skor pada setiap butir kategori dan skor akhir pengkajian resiko luka tekan Metode Waterlow. 
Tujuan dari penelitian ini adalah untuk mengetahui dampak pemberian terapi nafas dalam dan distraksi lima jari pada pasien pre operasi prostatektomi dengan masalah gangguan kecemasan atau ansietas.

\section{METODOLOGI}

Jenis penelitian ini adalah deskriptif dengan menggunakan metode pendekatan studi kasus. Studi kasus ini bertujuan untuk mengetahui dampak pemberian terapi nafas dalam dan distraksi lima jari pada pasien pre operasi prostatektomi di Ruang Kutilang RSUD Dr. Hi. Abdul Moeloek Propinsi Lampung dengan masalah gangguan kecemasan atau ansietas.

Respoden dalam penelitian ini adalah dua orang responden, yaitu pasien dengan kecemasan atau ansietas dengan rencana operasi prostatektomi (pre operasi).

Metode pengumpulan data yang digunakan pada kasus ini yaitu dengan wawancara (melakukan anamnesa, berisi tentang identitas pasien dengan segala keluhan yang dialami), observasi ( observasi dilakukan pada fisik maupun hasil data penunjang seperti USG dan hasil laboratorium pasien selama pengobatan dilakukan), dokumentasi ( dokumentasi dapat meliputi rekammedik maupun catatan perkembangan sebelum dan sesudah terapi dilakukan pada pasien dengan lembar observasi HRS-A. Penelitian ini dilakukan selama dua hari, terapi dilakukan sebanyak tiga kali dalam sehari dalam kurun waktu pemberian terapi 15-30 menit dalam sekali pemberian. Etika penelitian yang digunakan yaitu prinsip Benefience, prinsip menghargai martabat manusia (Respect human for dignity), dan prinsip keadilan (Justice).

\section{HASIL}

Pada saat pengkajian pada tanggal 2 Juli 2018 didapati Tn. A (44 tahun) sebagai responden pertama mengalami ansietas dengan rencana operasi prostatektomi pada tiga hari mendatang. Pada tanggal 9 Juli 2018 didapati responden kedua yaitu Tn. M (53 tahun) dengan masalah ansietas dan rencana operasi prostatektomi yang masih di jadwalkan oleh dokter. Hal-hal yang didapati pada Tn.A dan Tn.M yaitu keduanya sama - sama belum memiliki pengetahuan yang mendalam tentang penyakitnya juga nampak tidak tenang, kontak mata sangat sedikit dan wajah nampak sedih juga tidak bersemangat. Saat dilakukan pengkajian didapati nilai HRS-A pada Tn.A sebelum diberikan pendidikan kesehatan, relaksasi nafas dalam dan distraksi lima jariyaitu 21 (kecemasan sedang) sedangkan pada Tn.M didapati nilai HRS-A yaitu 28 ( kecemasan berat).

Dari data yang didapatkan pada Tn.A terdiagnosa BPH dan nefrolitiasis sinistra, Tn.A mengatakan perut bagian bawahnya nyeri dan nyeri berkurang setelah pasien terpasang kateter. Kecemasan dialami oleh 
Tn.A lantaran Tn.A belum memiliki pengalaman pembedahan sebelumnya dan takut akan keadaan yang akan terjadi setelah operasi dilakukan.

Tn.M terdiagnosa BPH dengan Susp. Tumor buli. Pada saat pengkajian pada tanggal 9 Juli 2018 pasien mengeluhkan nyeri pada perut bagian bawah dan terpasang kateter. Ansietas dirasakan pasien karena belum tersentuh oleh pelayanan kesehatan selama sakit yang dialami dan juga karena rencana operasi yang akan dialami pada beberapa hari mendatang. $\mathrm{BPH}$ yang disertai hematuri menyebabkan ansietas yang diderita oleh klien serta keluarga semakin meningkat lantaran mereka memiliki persepsi buruk dan pemikiran yang negatif terhadap penyakit yang diderita.

Setelah melakukan relaksasi nafas dalam dan distraksi lima jari pada kedua responden selama dua hari berturut - turut pada pukul 10.00, 14.00 dan 17.00 WIB dan diberikan pendidikan kesehatan pada hari pertama penelitian didapati hasil perhitungan HRS-A sebagai berikut :

Tabel 1. Tingkat Ansietas sebelum dan sesudah dilakukan relaksasi nafas dalam dan distraksi lima jari pada Tn.A

\begin{tabular}{cccc}
\hline $\begin{array}{c}\text { Hari } \\
\text { ke }\end{array}$ & Waktu & Sebelum & Sesudah \\
\cline { 1 - 1 } 1 & $10.00 \mathrm{WIB}$ & 21 & 20 \\
1 & $14.00 \mathrm{WIB}$ & 20 & 16 \\
& $16.30 \mathrm{WIB}$ & 16 & 10 \\
\hline \multirow{2}{*}{2} & $10.00 \mathrm{WIB}$ & 10 & 8 \\
& $14.00 \mathrm{WIB}$ & 8 & 5 \\
& $16.30 \mathrm{WIB}$ & 5 & 3 \\
\hline
\end{tabular}

Tabel 2. Tingkat Ansietas sebelum dan sesudah dilakukan relaksasi nafas dalam dan distraksi lima jari pada Tn.M

\begin{tabular}{cccc}
\hline $\begin{array}{c}\text { Hari } \\
\text { ke }\end{array}$ & Waktu & Sebelum & Sesudah \\
\cline { 1 - 3 } 1 & $10.00 \mathrm{WIB}$ & 28 & 24 \\
1 & $14.00 \mathrm{WIB}$ & 24 & 18 \\
& $16.30 \mathrm{WIB}$ & 18 & 15 \\
\hline \multirow{2}{*}{2} & $10.00 \mathrm{WIB}$ & 16 & 11 \\
& $14.00 \mathrm{WIB}$ & 11 & 6 \\
& $16.30 \mathrm{WIB}$ & 6 & 5 \\
\hline
\end{tabular}

Keterangan :

$<14=$ Tidak ada kecemasan

$14-20=$ Kecemasan ringan

$21-27=$ Kecemasan sedang

$28-41=$ Kecemasan berat

$42-56=$ Kecemasan berat sekali

Dari tabel diatas dapat terlihat menggunakan HRS-A melalui observasi peneliti, bahwa sebelum dilakukan relaksasi nafas dalam dan distraksi lima jari Tn.A mengalami ansietas sedang (jumlah score 21) namun setelah diberikan intervensi terapi selama dua hari berturut - turut ansietas Tn.A mengalami penurunan menjadi tidak ada ansietas (jumlah score 3). Tn.M sebagai klien II sebelum diberikan intervensi terapi mengalami kecemasan berat (jumlah score 28) namun setelah diberikan relaksasi nafas dalam dan distraksi lima jari ansietas Tn.M menurun yaitu tidak ada kecemasan (jumlah score 5). 


\section{PEMBAHASAN}

\section{Pengaruh Relaksasi Nafas Dalan dan Distraksi Lima Jari}

Sesuai dengan data demografi kedua responden memiliki usia diatas 40 tahun, yaitu 45 tahun dan 53 tahun dengan latar belakang pendidikan SMP dan SD dengan diagnosa BPH indikasi tindakan operasi prostatektomi, hal ini selaras dengan Banon (2014) yang mengatakan bahwa ansietas banyak dialami oleh pasien dengan tingkat pendidikan rendah, hal ini dimungkinkan karena ketidaktahuan pasien tentang penyakitnya yang dapat meningkatkan ansietas.

Tn.A dan Tn.M mendapatkan terapi pemberian relaksasi nafas dalam dan distraksi lima jari setelah dilakukan pengkajian dan pengukuran HRS-A. Setelah peneliti mendapatkan data Tn.A (kecemasan sedang) dan Tn.M (Kecemasan berat), kedua responden diberikan pendidikan kesehatan terlebih dahulu guna meningkatkan pengetahuan Tn.A dan Tn.M mengenai penyakit yang diderita dengan bantuan booklet. Kecemasan yang timbul pada kedua responden yaitu karena minim pengetahuan, ketakutan akan pembedahan yang akan dialami, keparahan penyakit yang diderita dan juga ketidakaktifannya pasien memeriksakan sejak dini penyakit yang diderita menimbulkan spekulasi buruk terhadap dirinya sendiri.
Mekanisme relaksasi nafas dalam distraksi lima jari dapat menurunkan ansietas yaitu adalah karena pada ansietas terdapat respon sistem saraf otonom terhadap rasa takut dan ansietas menimbulkan aktivitas involunter pada tubuh yang termasuk dalam pertahanan diri. Serabut saraf simpatis "mengaktifkan" tanda - tanda vital pada setiap tanda bahaya untuk mempersiapkan pertahanan tubuh. Kelenjar adrenal melepas adrenalin (epineprin), yang menyebabkan tubuh mengambil lebih banyak oksigen, mendilatasi pupil, dan meningkatkan tekanan arteri serta frekuensi jantung sambil membuat kontriksi pembuluh darah perifer dan memirau darah dari sistem gastrointestinal dan reproduksi serta meningkatkan glikogenolisis menjadi glukosa bebas guna menyokong jantung, otot, dan sistem saraf pusat. Ketika bahaya telah berakhir, serabut saraf parasimpatis membalik proses ini dan mengembalikan tubuh ke kondisi normal sampai tanda ancaman berikutnya mengaktifkan kembali simpatis (Videbeck, 2008).

Seperti pernyataan yang dikatakan oleh Videbeck (2008) hal ini sesuai dengan manfaat relaksasi nafas dalam dan distraksi lima jari, dimana relaksasi nafas dalam yang berguna untuk meningkatkan ventilasi paru dan meningkatkan oksigenasi darah (Smeltzer dan Bare, 2002). Hidayat (2009) juga mengatakan terapi relaksasi nafas dalam mampu memelihara pertukaran gas, 
mencegah atelektaksis, meningkatkan efisiensi batuk, dan mengurangi stress. Begitu pula distraksi lima jari yang merupakan salah satu self hipnosis bertujuan untuk memprogram diri, menghilangkan kecemasan dengan melibatkan saraf parasimpatis dan akan menurunkan peningkatan kerja jantung, pernafasan, tekanan darah dan kelenjar keringat serta lain sebagainya (Evangelista et $a l, .2016)$.

Setelah terapi relaksasi nafas dalam dan distraksi lima jari pada kedua responden selama dua hari berturut - turut pada pukul 10.00, 14.00 dan 17.00 WIB dan diberikan pendidikan kesehatan menjelang operasi, didapati hasil pengukuran ansietas dengan HRS-A yiatu, Tn.A mengalami penurunan menjadi tidak ada ansietas (jumlah score 3). Sedangkan Tn.M menurun yaitu tidak ada kecemasan (jumlah score 5).

Sesuai dengan penelitan di RSUD RA Kartini Jepara, pemberian terapi relaksasi nafas dalam sangat berdampak pada penurunan tingkat ansietas pada pasien pre operasi. Pada penelitian tersebut menyebutkan bahwa pemberian terapi nafas dalam pada pasien pre operasi yang mengalami cemas memiliki dampak yang baik. Dampak tersebut nampak dalam 15 menit setelah diberikan terapi nafas dalam, pasien dengan ansietas berat tidak lagi mengalami ansietas setelah diberikan terapi relaksasi nafas dalam. Hal ini dapat diartikan bahwa relaksasi nafas dalam efektif untuk menurunkan kecemasan pre operasi (Aprianto et al,. 2013). Sedangkan distraksi lima jari atau hipnotis lima jari merupakan salah satu bentuk self hipnosis yang dapat menimbulkan efek relaksasi yang tinggi, sehingga akan mengurangi ketegangan dan stress dari pikiran seseorang (Hastuti dan Arumsari, 2015).

\section{KESIMPULAN}

Berdasarkan penelitian yang telah dilakukan didapati penurunan ansietas pada Tn.A dan Tn.M setelah dilakukan intervensi relaksasi nafas dalam dan distraksi lima jari. Sebelum dilakukan intervensi, Tn.A mengalami ansietas sedang (total HRS - A yaitu 21) sedangkan Tn.M mengalami ansietas berat (total HRS - A yaitu 28). Setelah intervensi dilakukan selama 2 hari berturut - turut dalam pemberian waktu 3 kali sehari, Tn.A tidak lagi mengalami ansietas (total HRS - A yaitu 3) dan juga Tn.M tidak lagi mengalami ansietas (total HRS - A yaitu 5). Maka peneliti dapat menarik kesimpulan bahwa relaksasi nafas dalam dan distraksi lima jari efektif untuk mengatasi masalah ansietas pre operasi prostatektomi Tn.A dan Tn.M.

\section{KEPUSTAKAAN}

Aprianto, D., Kristiyawati, S P., Purnomo, S.Eko Ch. (2013). Efektifitas Teknik Relaksasi Imajinasi Terbimbing dan Relaksasi Nafas Dalam Terhadap Penurunan Kecemasan Pada Pasien Pre Operasi. Semarang 
Banon, et al. (2014). Efektivitas Terapi

Hipnotis Lima Jari untuk Menurunkan

Tingkat Ansietas Pasien Hipertensi. 2(3)

Bare \& Smeltzer (2002). Buku Ajar

Keperawatan Medikal Bedah Brunner \& Suddart. (Alih bahasa Agung Waluyo)

Jakarta: EGC

Evangelista, T., Widodo, D,. Dan Widiani, E. (2016). Pengaruh Hipnosis 5 Jari Terhadap Tingkat Kecemasan Pasien Sirkumsisi Di Tempat Praktik Mandiri Mulyorejo Sukun Malang. Volume 1 Nomor 2. Malang.

Hastuti, R Y., Arumsari, A. (2015). Pengaruh Terapi Hipnotis Lima Jari Untuk Menurunkan Kecemasan Pada Mahasiswa Yang Sedang Menyusun Skripsi Di Stikes Muhammadiyah Klaten. Volume 10 Nomor 21. Klaten.

Rokawie, A O N., Sulastri., dan Anita. (2017). Relaksasi Nafas Dalam Menurunkan Kecemasan Pasien Pre Operasi Bedah Abdomen. Tanjung Karang.

Sari, A D K., Subandi. (2015). Pelatihan Teknik Relaksasi Untuk Menurunkan Kecemasan Pada Primary Caregiver Penderita Kanker Payudara. Volume 1 Nomor 3. Universitas Gajah Mada.

Videbeck, S L. (2008). Buku Ajar Keperawatan Jiwa. Jakarta. EGC. 